\title{
Scout Participation in Public Health Activities in the Jabodetabek Region in 2020
}

\author{
P. A. Kodrat Pramudho', \\ Armalia Reny ${ }^{2}$ \\ ${ }^{1}$ Public Health Master Program, \\ Univesity of Mitra Indonesia \\ ${ }^{2}$ Business Faculty Program, \\ University of Mitra Indonesia
}

Email:

kodratadiyono@gmail.com

Received: October 5, 2020

Accepted : November 27, 2020

Published : November 30, 2020

\begin{abstract}
Health problems cannot be solved by health officials alone. The scout movement with millions of members throughout Indonesia clearly has a very important role. Scout members as millennial youth can be important agents of change, both for fellow youths, for parents and their families as well as for society as a whole. The study aims to observe the participation of the Ventura Scout and Rover Scouts who carry out various activities in the public health in the Jabodetabek area and which media cover/report on these Scouting activities. The research is qualitative in nature by observing news of Scout involvement in the public health activities in electronic mass media, print media and online media from January to June 2020. To complete the information, the researchers conducted in-depth interviews with several connected coaches and scouts. The analysis is carried out simply by comparing which media do the most news coverage/broadcasting about scout activities in the publicc health activities, and what motivations make scouts involved in public health activities.

The research results showed that the of Ventura Scoutand Pandega Scouts were heavily involved in the public health activities, especially during the Covid19 pandemic, among others, distributing masks, becoming counselors, becoming role models. The conclusion is that Scout involvement in the public health activities is quite often carried out in the Jabodetabek area in accordance with existing health problems in the local location. Scouts have been motivated to carry out humanitarian activities because of the pledge and promises contained in Tri Satya and Darma Pramuka. The recommendation forward are every Scout carrying out activities in the health sector must be equipped with PPE (personal protective equipment) and the Scout Movement must continue to collaborate on an ongoing basis with the mass media, both printed, electronic and online.
\end{abstract}

Keywords: Scouts, public health, mass media

Copyright (C) 2020 IIK STRADA Indonesia All right reserved.

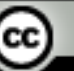

This is an open-acces article distributed under the terms of the Creative Commons Attribution-ShareAlike 4.0 International License.

\section{Background}

Public health problems cannot be solved by the health apparatus alone. The Scout Movement with a total membership of 23 million students who are from the Club Scouts (7-10 years), Boy Scouts (11-15 year), Ventura Scout (16-20 years) and Rover Scouts (21-25 years) spread across 
throughout Indonesia (Kwarnas Scout Movement, 2019). Scout members clearly have a very important role in the public health, especially disease prevention and health promotion for both their members and the community around where they live. Scout members as millennial youth can be important agents of change, both for fellow youths, for their parents and families as well as for society as a whole.

In accordance with the promises and commitments of each member in Tri Satya and DarmaPramuka, among others, they are ready to help others in life and participate in building society. The Scout Movement as a non-formal education organization that complements formal education in schools and informal education in the family. Scout members, in the future will become members and community leaders. The number of Ventura Scouts and Rover Scouts in Indonesia is around 3.6 million (16\% of 23 million Scouts). The Scout Movement has great potential in carrying out community service and has been carried out in many ways including public health activities. Many activities of the Scout Movement in the health sector, especially efforts to promote health and disease prevention, such asclean and helthy lifestyle (PHBS), Healthy Community Movements (Germas) Immunization, discovery and assistance for pulmonary TB cases, maternal and child health, adolescent health, anti-smoking and anti-drugs as well as Covid19 control, which focuses on wearing masks., wash your hands frequently with soap (CTPS), and keep your distance. For a long time, the Scout Movement has been actively involved in helping and helping sufferers affected by disasters such as fires, landslides, tornadoes, floods and so on.

The study aims to observe the involvement of the Penegak Scout and Pandega Scouts who carry out various public health activities in the Jabodetabek area (Jakarta, Bogor, Depok, Tangerang and Bekasi) and which media have covered/reported on these Scouting activities during January to June 2020.

\section{Research methodology}

Qualitative research by observing news of the involvement of the Ventura Scout and Pandega Scouts in the public health activities in electronic mass media, print media and online media. From January to June 2020, this is included in the current Covid19 pandemic. To complete the information, the researcher conducted in-depth interviews with several scout advisors and scouts who could be connected. The analysis is carried out simply by comparing which media do the most coverage/news broadcasting about scout activities in the public health, and the motivation of the scout brothers to be involved in these public health activities.

Sources of research data are news about Scout activities in the public health which are covered by electronic media, print media, and online media which are published in online media. Another source of data is the Scouts and Scout Guards or Pamong Saka Bakti Husada who are willing to become informants. The data was collected by researchers by browsing on google search from January to June 2020. Meanwhile, in-depth interviews with several informants confirmed their main motivation to carry out activities in the health sector.

Data processing and analysis were carried out in descriptive and qualitative ways, namely 1) identifying activities in the health sector and what topics were mostly carried out by Scouts for 6 months in the Jabodetabek area, 2) identifying which media contained the most public health activities carried out by Scouts in Jabodetabek area, and 3) processing informant data obtained by means of indepth interviews. Analysis of the content of the news was not carried out, but researchers only saw whether or not the news of Scouting activities in the public health was published by the mass media.

\section{Results and Discussion}

Based on the qualitative analysis of research data, the results listed below can be presented

Table 1. Most activities in the public healthare carried out by Scouts during January-June in the Jabodetabekarea, 2020

\begin{tabular}{ll}
\hline \multicolumn{1}{c}{ Health Activities } & \multicolumn{1}{c}{ Health Activities } \\
\hline Covid-19 Counseling & Avoid Seduction to Smoking \\
Campaign using masks & Immunization for babies \\
CTPS Campaign & Maternal and Child Health \\
\hline
\end{tabular}




\begin{tabular}{ll}
\hline Care for Tuberculosis & Cama to Posyandu \\
Care for Jabodetabek Floods & Care for Non comunicable diseases \\
Fight Garbage & Distributing groceries \\
Drugs no way & Helping disater victims \\
\hline
\end{tabular}

Based on the Table 1. Scouts throughout Jabodetabek have carried out many activities in the health sector and the most popular are activities related to the prevention and control of Covid19 starting from distributing masks, counseling using masks and washing hands frequently with soap (CTPS). Then, sequentially, the activities to find TB cases and accompany patients to take medication. This was inspired by the words of President Jokowi, namely TOSS TB (Find Cure Until Heal Tuberculosis). Then the activity that is of interest to the Scouts is to care about floods, especially in early 2020, almost as much as Jabodetabek was hit by floods due to high rainfall. The Scouts' role began to help evacuate flood-affected residents, providing motivation and entertainment to children in evacuation sites. Likewise, the problem of garbage has also received scouts' attention, especially in the aftermath of the flood, and has also participated in campaigning for throwing garbage in the trash, not on the streets. The problem of drugs and not being seduced by cigarettes is also a concern of Scouts throughout Jabodetabek, especially on World No Tobacco Day, May 31, 2020 and International Anti-Drug Day, June 26, 2020.

Activities to get babies and children immunized are also one of Scouts' concerns, especially in Bodetabek. While activities related to maternal and child health, especially for mothers to come to Posyandu in several locations, also did not escape the scouts' attention. Matters related to noncommunicable diseases (PTM) are also a matter of community service by campaigning for CERDIK for the community, especially young people who have risks such as obesity and hypertension in their neighborhood. CERDIK stands for routine health checks, get rid of cigarette smoke, be diligent in exercising, a balanced diet, get adequate rest and manage stress. Activities that are often also carried out by Scouts are helping to distribute basic necessities or during the month of Ramadhan in many locations throughout Jabodetabek, Scouts are active in groups distributing takjil to the community at intersections, stations, bus terminals, or locations where many people pass by. Scouting activities that are mostly carried out are helping victims of disasters such as landslides, tornadoes, fires, etc.

Since the Covid19 pandemic hit the whole world including Indonesia, there have been many PandegaScouts and Ventura Scout who have been involved in preventing the transmission of Covid19, namely always wearing masks, sharing masks, always maintaining distance and handwashing with soap, distributing PPE (personal protective equipment)for health workers at health centers and hospitals, becoming extension agents. Peer groups, a reminder of the community to abide by health protocols, become role models for other young people. Even AnisBaswedan, the Governor of DKI Jakarta, specifically asked the Scouts to show obedience and discipline to health protocols.

Several Scouts and Scout Guards who were interviewed by researchers after being asked why Scouts want to do health care for the community, they answered in essence that it is the duty of fellow humans to help each other. Indeed, according to the author's opinion, the Scout Movement has a promise and commitment to every Scout member, namely Tri Satya and DarmaPramuka.

In the Tri Satya which is repeated every year by every Scout, namely "For my honor I promise to seriously carry out my obligations towards God Almighty and the Unitary State of the Republic of Indonesia, practice Pancasila, help others in life, participate in building society, and fulfill the DasaDarma".While the Scout Darma that is relevant to Scouting concerns, namely the second darma (love of nature and compassion for fellow humans) and the fifth darma (Willing to help and be steadfast). So the issue of community care and service for Scouts is something that must be done because they keep their promises and commitments as Scout members. However, there are still many scouts who care about the health sector that they are not equipped with personal protective equipment (PPE) which will reduce the risk of danger or accidents.

Seeing table 2 about the mass media covering and reporting on Scouting activities in the health sector during January-June 2020 in the Jabodetabek area the most of which are social media consisting of WA, FB, Youtube, Instagramand Twitter because they are Scouts involved in community service that cover and uploading to social media networks. This is also based on the tagline "Every Scout is a reporter" which is a kind of obligation for every Scout who does outdoor activities to upload his activities in the form of photos, writings or videos in their respective social 
media accounts. Meanwhile online media likes to report scouting activities in the health sector because the contributor is the scout himself who is involved in the activity.

Electronic media in the form of television or radio can be identified which often cover scouting activities in the public health besides TVRI and RRI as well as private television and local radio or community radio in the Jabodetabek area. Although limited, it turns out that there are still printed media that report on health activities for Scouts in the Jabodetabek area such as the Tribune News, Kompas, Republika, Koran Tempo, Warta Kota and local newspapers. Seeing the above reality, it is necessary for the mass media to continue to be motivated to be willing to report Scouting activities which have a positive impact on youth and the millennial generation so that Scouts can be the choice of young people to do good. It is necessary for Kwarnas and Kwarda for the Scout Movement to continuously collaborate with the mass media so that the positive image of Scouts can be widely spread so as to support character education for Indonesian youth.

Table 2. Mass Media Covering/ReportingScouting activities in the public health during January-Junein the Jabodetabek area in 2020

\begin{tabular}{lll}
\hline Sosial Media & Elektronic Media & Print Media \\
\hline Whatsaap & SCTV & Tribune News \\
Facebook & TVOne & Kompas \\
Youtube & RCTI & Republika \\
Instagram & Radio Elshinta & Koran Tempo \\
Twitter & TVRI & Warta Kota \\
Pramuka or.id & RRI & Pos Kota \\
Scout Web Area & Scout Radio & Radar Bogor \\
Detik Health.com & Tcommunity/TV Local & Radar Bekasi \\
Newsroom Tempo & Community Radiao & Tangsel Pos \\
Liputan 6.com & & \\
Other online media & & \\
\hline
\end{tabular}

\section{CONCLUSIONS AND RECOMMENDATIONS}

The involvement of Ventura Scout and Pandega Scouts in the health sector is quite often carried out in the Jabodetabek area according to the health problems that exist in the local location. The Scouts of Venturaand Rover Scouts have been motivated by carrying out humanitarian activities because of the pledge and promises contained in Tri Satya and DarmaPramuka. The online media that mostly reports on Ventura Scouts and Rover Scouts because the tagline is that "every Scouts is a reporter" and Scouting activity in the public health must be equipped with PPE (personal protective equipment)which will reduce the risk of danger or accidents, and the Scout Movement must continue to collaborate continuously with good mass media.print, electronic and online. Thanks.

\section{REFERENCES}

Kwarnas Scout Movement. (2010). Scout Movement Revitalization

Scout Movement. (2018). Results of the Scout Movement National Conference in Kendari, Southeast Sulawesi.

Kwarnas Scout Movement. (2018). Scout Movement Strategic Plan 2019-2024. Results Scout Movement National Conference in Kendari, Southeast Sulawesi,

Kwarnas Scout Movement. (2008). Guidelines for Organizing Scouting Units

Kwarnas Scout Movement Guidelines for Scouting Work Units Bakti Husada, 2011

Liputan SCTV. (2020). Liputan 6: news related to scouts in health activities.

Moleong. (2017). Qualitative Research Methodology.

RCTI Coverage. (2020). News regarding health in scouting activities.

TVRI and RRI coverage of health news involving scouts, 2020

Wibowo, Adik. (2015). Health Research Methodology (Concept and Application). 